\title{
Managing Confidence in Emerging Market Bank Runs
}

Se-Jik Kim and Ashoka Mody 


\title{
IMF Working Paper
}

European Department and Research Department

\section{Managing Confidence in Emerging Market Bank Runs}

\author{
Prepared by Se-Jik Kim and Ashoka Mody ${ }^{1}$
}

December 2004

\begin{abstract}
This Working Paper should not be reported as representing the views of the IMF. The views expressed in this Working Paper are those of the author(s) and do not necessarily represent those of the IMF or IMF policy. Working Papers describe research in progress by the author(s) and are published to elicit comments and to further debate.

In a rational-expectations framework, we model depositors' confidence as a function of the probability of future bank bailouts. We analyze the effect of alternative bank bailout policies on depositors' confidence in an emerging market setting, where liquidity shortages of banks are revealed sequentially and governments cannot credibly commit to bailing out all potentially distressed banks. Our findings suggest that allowing early bank failures and using available liquidity for credible commitments to later bailouts can better boost confidence than early bailouts. This conclusion arises because with a high chance of liquidity shortage in the future, depositors may lose confidence and hence withdraw deposits even from potentially sound banks. Such a policy of late bailouts is likely to receive political support when a full bailout needs to be financed by taxation. The logic of late bailout remains valid even when banks may hide their distress or when closures of early distressed banks create contagion.
\end{abstract}

JEL Classification Numbers: G1, G2

Keywords: Confidence, bank runs, bailout, sequential liquidity shortages

Author(s) E-Mail Address: skim@imf.org; amody@imf.org

\footnotetext{
${ }^{1}$ The authors are grateful for comments from Enrica Detragiache, Simon Johnson, Jonathan Ostry, Raghuram Rajan, and Carlos Vegh.
} 


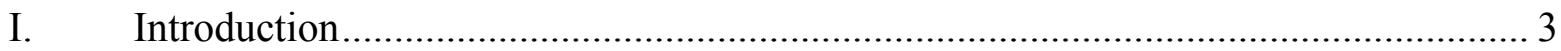

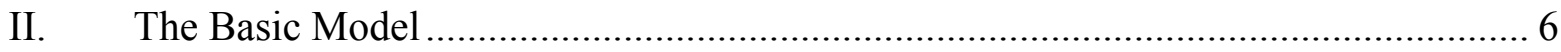

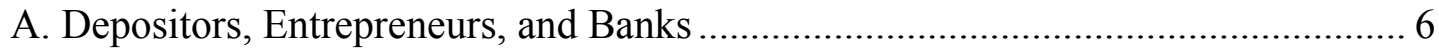

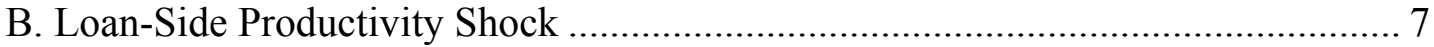

C. Aggregate Shock and Liquidity Shortages.................................................... 8

D. Lender of Last Resort and Bailout .................................................................... 10

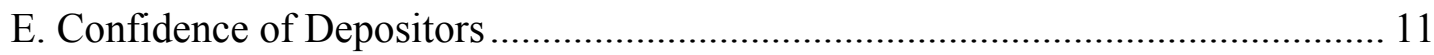

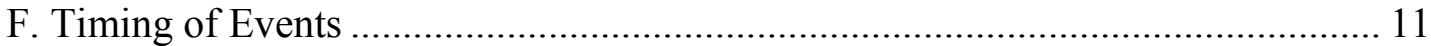

III. Simultaneous Versus Sequential Liquidity Shortages ...................................... 12

A. Bailout Under Simultaneous Liquidity Shortages ......................................... 12

B. Random Bailout Under Sequential Liquidity Shortages ................................. 13

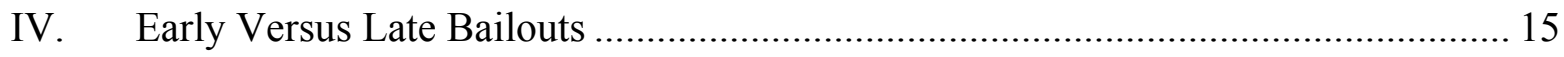

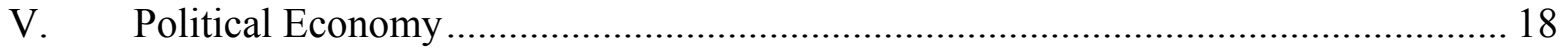

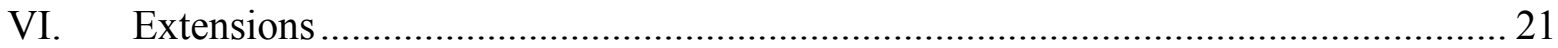

A. Blanket Guarantees and Preemptive Bank Closures.......................................... 21

B. Potential Crisis Delays Through Information Hiding ...................................... 23

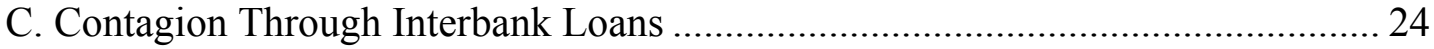

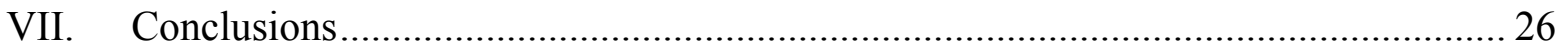

\section{Text Tables}

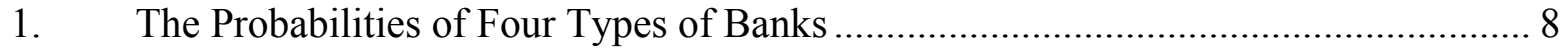

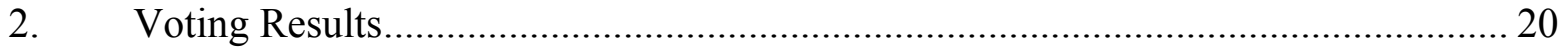

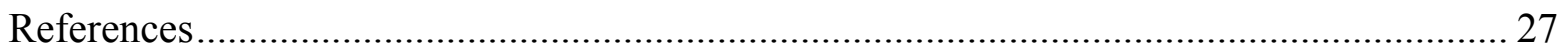




\section{INTRODUCTION}

Banking crises unfold over time. Initially, the weak liquidity position of some banks is revealed when they face unexpected delays in loan repayments. Depositors in other banks, suspecting more widespread weaknesses, are liable to trigger runs even on banks that are financially sound. Governments, therefore, need to manage the confidence of depositors once the problems in a segment of the banking system become public knowledge. Managing confidence, however, is not straightforward if a government cannot generate sufficient liquidity to bail out all banks that may eventually face distress.

In a rational-expectations framework, we model depositors' confidence as a function of the probability of future bank bailouts. This model allows an analysis of the optimal bailout policy of a budget constrained government. Managing confidence becomes crucial to prevent bank runs because the government can credibly offer only partial bailouts. Unlike in existing bank run models, confidence in our model is endogenously determined as a function of bank bailout policy. ${ }^{2}$ While the traditional examination of bank runs has focused on the liquidity positions of banks, we highlight, instead, the confidence effect of bailout policies conducted by a government with liquidity constraints. Such constraints are likely to be especially relevant in emerging markets, where government credibility is always fragile; institutional arrangements, such as a currency board or dollarization, limit the central bank's ability to act as a lender of last resort; and the possibility of large fiscal deficits can generate speculative attacks. ${ }^{3}$ In such conditions, specifically, should banks with early signs of distress be bailed out or should they be allowed to close down? And would an optimal sequence of bailouts receive public support?

In practice, the bailout paths conventionally chosen by governments have often failed to restore confidence and may even have exacerbated the crises. In August 1997, the Korean government, facing deteriorating investor confidence following the collapse of Kia motors and the sharp decrease in the value of the Thai baht, announced a blanket guarantee on overseas borrowing by Korean financial institutions. The government then rescued Korea First Bank, the main bank of troubled Kia, in September 1997. Despite these immediate efforts to stem an incipient crisis, the country suffered further deterioration of confidence as the Bank of Korea's foreign reserves were depleted, and an IMF-supported program was needed to restore stability (see Chopra and others, 2002). Similarly, in Uruguay in early 2002, the government, facing financial turbulence starting from two private banks, announced a plan to provide liquidity support to public and

\footnotetext{
${ }^{2}$ Confidence has often been viewed as being affected by an extraneous belief or a sunspot which is not directly linked to the central authority's policy (e.g., Krugman, 1998). In our model, by contrast, confidence is directly affected by fundamentals, particularly aggregate liquidity conditions, which, in turn, are influenced by bailout policy.

${ }^{3}$ The absence of policy credibility in emerging markets (owing to weak institutions) tends to induce huge foreign currency-denominated deposits and borrowings (see, e.g., Rajan, 2004). There is a growing literature on the role of policy credibility and weak institutions in emerging markets (e.g., Diamond, 2004; Johnson and Mitton, 2003; and Mody, 2004).
} 
private banks. However, dollar deposit outflows accelerated, leading to the government's declaration of a bank holiday on July 30 .

Thus, when the first signs of a banking crisis appear, the government's attempt to halt a systemic loss in confidence by bailing out the banks in trouble at that time and announcing its willingness to rescue any distressed bank in the future as well may not be credible when liquidity constraints are evident - that is when the government cannot support banks with early and late occurrences of distress. Indeed, commitment to a policy of full bailouts may, in such a situation, trigger fears of a banking crisis, accelerating the withdrawal of deposits, including, importantly, from financial institutions that are otherwise sound. ${ }^{4}$

But such a risk arising from the promise of a full bailout does not imply that the government has no role to play. Absent some commitment to prevent bank runs, the economy may suffer large costs through premature termination of projects. The question we therefore ask is whether a partial bailout, feasible within the government's resource constraint, offers a more attractive policy option for managing confidence than the two extremes of no bailout or a full bailout. More importantly, we ask what type of partial bailouts will bring about the optimal outcome in sequential liquidity crises. ${ }^{5}$

We conclude that under sequentially revealed liquidity shortages, confidence will be boosted more and the incidence of bank runs, more limited when the bailout is reserved for banks revealed to be vulnerable at a later stage rather than banks facing early liquidity shortages. Bailout of illiquid banks today risks raising the probability of a shortage of liquidity with which to bail out illiquid banks in the future. Viewing such early bailouts, depositors of all the banks whose liquidity condition will be revealed only in the future (including the otherwise sound banks) may lose confidence (i.e., expectation that their deposits will be fully protected) and run to withdraw their deposits. To prevent such an economy-wide loss of confidence, the government may need to reassure depositors that there will be no liquidity shortage in the future. For this, the government may, by closing illiquid banks today, save sufficient liquidity to bail out all the illiquid banks in the future. In contrast, other forms of partial bailout may fail to maintain confidence. For example, the promise of a uniform partial bailout of all distressed banks will not be credible since depositors will be concerned about the lack of financial capacity to bail out banks that may need support in the future.

\footnotetext{
${ }^{4}$ In an open-economy context, it would instead generate fiscally generated currency crisis if the central authority attempts to avoid a banking crisis. Burnside, Eichenbaum and Rebelo (2001) suggest that exogenous arrival of new information about large future deficits can generate speculative attacks.

${ }^{5}$ Sequential liquidity crises in emerging markets reflect high concentration of bank loans on a small number of large firms with close relationships, and sequential occurrence of productivity shocks across borrower firms (owing to differences in time-to-build technology or production chains of upstream and downstream industries (Blanchard and Kremer, 1997)).
} 
This paper presents a model of confidence and bailout by introducing sequential liquidity shocks into a bank run model. Banks differ in the timing of loan-side shocks: there are morningshock banks and afternoon-shock banks. An adverse loan-side shock and the resulting illiquidity of a bank occur where borrower firms experience delays in realizing returns from their projects (modeled as "late projects"). Thus, the differentiation between illiquid and liquid banks is first identified for morning-shock banks while the liquidity conditions of afternoon-shock banks remain unknown at that time. In this setup, depositors in afternoon-shock banks formulate confidence by making rational expectations about the safety of their deposits based on information on the government's financial constraints and bailout policies. When they lose confidence owing to a bailout policy, depositors may run even before they know the liquidity conditions of their banks. Hence the government's bailout decisions in the early stages of a liquidity crisis, when the liquidity conditions of only a part of the banking system are known, are crucial in determining whether confidence will be maintained in the rest of the system.

We also explore the political economy of bailouts when additional taxation is required to bail out illiquid banks. We find that a late bailout without taxation is likely to receive more public support than a full bailout financed by taxation. Under the policy of late bailouts, a significant fraction of depositors are likely to have their deposits protected. Under a full bailout financed by taxation, however, depositors would have to pay taxes using their deposits, leading to lower after-tax consumption.

Finally, we deal with two potential considerations that may suggest early bailouts. First, knowing that the government will bail out those banks with later signs of distress, some banks may engage in an effort to hide their early distress. We argue, however, that if the technology to hide distress is equally available to all, then the optimality of a late bailout policy does not change. If some are able to hide their distress longer than others, the response to that should be a strengthening of late bailout policy, possibly supported by regulatory tightening to ensure transparency. Second, if closure of early-distress banks leads to contagion (through interbank loans they have obtained from afternoon-shock banks), dealing with early distress might become more relevant. We show, however, that if the shock is large enough, the liquidity drain from bailing out early-distress banks would make it undesirable to do so even in the presence of contagion.

This paper is related to the classic paper on bank runs by Diamond and Dybvig (1983) and two recent papers on bank bailouts by Diamond and Rajan $(2002,2003)$ in which the authors point out the possibility that bank bailouts can exacerbate aggregate liquidity shortages. There are, however, major differences between the existing bank-run models and ours. First, we introduce loan-side shocks that are revealed sequentially across banks, while the existing models assume simultaneous shocks. By introducing such dynamics, our model allows us to draw distinctions among banks based on the amount of information revealed, apart from their liquidity positions. As a result, we can analyze how a bailout of banks whose liquidity shortages are already revealed influences the confidence (or rational expectations) of depositors in other banks whose liquidity conditions will be known only in the future. Second, by focusing on different confidence effects between banks with early and late shocks, our model addresses the issue of 
the optimal bailout policy and generates an important policy option: bailout of late-distress banks. ${ }^{6}$ Finally, as noted, we examine the political economy implications of different bailout policies and the voting equilibrium. In this way, our model goes beyond assuming financially constrained governments and provides an explanation of why the government's ability to carry out bailouts financed by taxation could be limited. ${ }^{7}$

The remaining sections of this paper are organized as follows. Section II presents the basic model. Section III examines bailouts under simultaneous and sequential liquidity shortages, and Section IV compares bank runs with early bailouts and late bailouts. In Section V, we analyze a late bailout policy as a voting equilibrium. Section VI discusses some extensions of the model, in particular the consequences of information hiding by banks and the implications of contagion. Section VII concludes the paper.

\section{THE BASIC MODEL}

The model economy, incorporating sequential liquidity shocks across banks, consists of three types of agents: depositors, entrepreneurs, and banks. The economy has three dates, $t=0,1$, and 2 , while date 1 is divided into two sub-periods, $\mathrm{s}=1$ and 2 .

\section{A. Depositors, Entrepreneurs, and Banks}

There is a continuum of risk-neutral depositors defined on the interval [0,1]. Each depositor has an endowment (whose value is normalized to be 1), which, for simplicity, we assume is deposited in only one bank. ${ }^{8}$ The demand deposit contract allows the depositor to withdraw the full value of the deposit $(=1)$ at any time.

\footnotetext{
${ }^{6}$ Diamond and Rajan do not explicitly address the issue of optimal bailout policy, possibly because in their setup, unlike in our model, liquidity information is revealed simultaneously across all the banks (liquid or illiquid), and the optimal policy is rather straightforward: bailing out more liquid banks rather than illiquid banks.

${ }^{7}$ This paper is also related to the literature on the domestic or international lender of last resort (e.g., Goodhart and Huang, 2000; Lerrick and Meltzer, 2003; Jeanne and Wyplosz, 2001; Cordella and Yeyati, 2003; Kim, 2004). Most studies in the literature focus on the moral-hazard effect of bailouts. In contrast, this paper focuses on the effect of bailouts on the aggregate resource constraint. Among the existing studies focusing on moral hazard, Kim (2004) is most closely related to this paper. It suggests that a timing-based policy (of not rescuing a country where a crisis first occurs but any country that suffers a subsequent crisis) may effectively mitigate moral hazard, and at the same time, contain crisis contagion.

${ }^{8}$ Risk-neutral depositors do not have an incentive to diversify deposits across banks. Even if we assume risk averse depositors who diversify their deposits across banks, the main results of the paper would not be altered.
} 
The economy has a continuum of entrepreneurs defined on the interval $[0, \mathrm{~m}]$, each endowed initially with nothing but managing a project that requires input of goods at date 0 . To engage in production, the entrepreneur has to borrow from a bank. The project, financed by bank loans, produces $\mathrm{C}$ unit of goods for a unit of goods input unless the production process is terminated before completion. Projects may differ in the timing of completion. Some projects are completed at date 1 and others at date 2. As in Diamond and Dybvig (1983), we call the former early projects, and the latter late projects. Projects that are completed late generate a liquidity problem since those entrepreneurs are unable to repay their loans in period 1. If a project is terminated before completion, it yields c (for a unit of goods input) immediately. Such premature termination of a project is costly, with $\mathrm{c}<1<\mathrm{C}$. There is uncertainty at date 0 whether a project is of the early or late type.

A continuum of risk-neutral bankers, defined on the interval $[0, n]$, have no endowments in the initial period but have specific knowledge of firms, similar to Diamond and Rajan (2001). Each banker has her own bank, and lends the deposits it receives to entrepreneurs. If an entrepreneur produces $\mathrm{C}$, she pays $\gamma \mathrm{C}$ to the bank and has the remainder, $(1-\gamma) \mathrm{C}$, for her own consumption. The relationship banking allows the bank to collect $\gamma$ portion of output from borrower firms.

We assume that each depositor has an utility function that depends on the consumption of date 1 but not on the consumption of date 2 (that is, $\mathrm{u}\left(\mathrm{c}_{1}, \mathrm{c}_{2}\right)=\mathrm{c}_{1}$ where $\mathrm{c}_{1}$ is the consumption at date 1 and $c_{2}$ is consumption at date 2), while the utility of an entrepreneur or a banker depends only on her consumption at date 2 (as in Diamond and Rajan $(2002,2003)$ ). ${ }^{9}$ In addition, depositors have lexicographic preferences such that they prefer early deposit withdrawal to waiting if the payoff of the former is greater than the latter, but prefer waiting if the payoff of the two options are the same.

The population of depositors is far larger than those of entrepreneurs and bankers. This is a reasonable assumption in view of the fact that the number of firms and banks in any economy is very small compared to that of depositors. In particular, assume that $m$ and $n$ are positive but close to zero, which implies that the measure of bankers and entrepreneurs relative to that of depositors goes to zero (which simplifies the discussion of the voting equilibrium in Section 5).

\section{B. Loan-Side Productivity Shock}

Our model deviates from the existing bank run models by allowing loan-side shocks of banks to occur sequentially within date $1(\mathrm{t}=1)$. Specifically, date 1 is divided into two sub-periods $(\mathrm{s}=$ 1 and $\mathrm{s}=2$ ), over which loan-side shocks of banks occur (and are revealed). For some banks, the shock occurs in the "morning" $(\mathrm{s}=1)$ and for others in the "afternoon" $(\mathrm{s}=2)$. The fraction of banks that receive a shock in the morning is $\varphi$, with the rest $(1-\varphi)$ receiving a shock in the afternoon.

${ }^{9}$ Of course, we may instead assume that a fraction of depositors have preference shocks on date 1 (i.e., $\left.\mathrm{u}\left(\mathrm{c}_{1}, \mathrm{c}_{2}\right)=\mathrm{c}_{1}\right)$ and the rest on date 2 (i.e., $\mathrm{u}\left(\mathrm{c}_{1}, \mathrm{c}_{2}\right)=\mathrm{c}_{2}$ ), which would not affect the main results. 
Given the fact that at the start of a banking crisis, a majority of depositors are usually uninformed about the liquidity condition of their banks, it would be reasonable to assume that $\varphi$ is not greater than a half $(\varphi \leq 1 / 2)$. For simplicity, assume below that $\varphi=1 / 2$ (note that assuming that $\varphi<1 / 2$ does not alter the result). At date $0, \varphi$ is known, but the identities of the banks that will receive the shocks in the morning and afternoon are not known.

Further, a morning-shock bank or an afternoon-shock bank in our model may be type-L or type$\mathrm{H}$ banks, where type-L banks make loans only to borrowers with late projects and type-H banks lend only to early projects. ${ }^{10}$ Thus banks here can be classified into four types: L1, H1, L2, H2, where L1 represents late-project morning-shock banks, H1 early-project morning-shock banks, $\mathrm{L} 2$ late-project afternoon-shock banks, and $\mathrm{H} 2$ early-project afternoon-shock banks. At date 0 , the type is not known to anybody.

The fraction of type- $\mathrm{L}$ is denoted by $\alpha$ among morning-shock banks and by $\beta$ among afternoonshock banks. In good times, fewer banks will experience liquidity problems (and, hence, small $\alpha$ and $\beta$ ). But in recession or crisis, the share of banks with liquidity problems may rise, leading to higher $\alpha$ and $\beta$. Since we assumed above that half the banks receive a shock in the morning, the distribution of the four types is given by: $\alpha / 2$ for type $L 1,(1-\alpha) / 2$ for type H1, $\beta / 2$ for type L2, and $(1-\beta) / 2$ for type $\mathrm{H} 2$.

Table 1. The Probabilities of Four Types of Banks

\begin{tabular}{|c|c|c|}
\hline & Morning shock (1) & Afternoon shock (2) \\
\hline Late project (L) & $\alpha / 2$ & $\beta / 2$ \\
\hline Early project $(\mathrm{H})$ & $(1-\alpha) / 2$ & $(1-\beta) / 2$ \\
\hline
\end{tabular}

\section{Aggregate Shock and Liquidity Shortages}

An adverse aggregate shock can lead to a series of liquidity shortages across morning-shock and afternoon-shock banks. Given the utility function of depositors $\left(\mathrm{u}\left(\mathrm{c}_{1}, \mathrm{c}_{2}\right)=\mathrm{c}_{1}\right)$, each depositor's demand for liquidity from her bank at date 1 is one, regardless whether it is a type-L or type-H

\footnotetext{
${ }^{10}$ This assumption reflects the fact that banks in emerging markets often concentrate their credits to a small set of large borrower firms rather than fully diversify across all the firms. For example, Korea First Bank lent more than 130 percent and 90 percent of its paid-in capital to Hanbo Steel and Kia Motors, respectively, before their collapses in 1997. If the banks fully diversify their lending across firms, all the banks will have the same shock at the same time, so that there will be no distinction among L1, H1, L2, and $\mathrm{H} 2$ type.
} 
bank. Then aggregate demand for liquidity is $1 / 2$ in each of $s=1$ and $s=2$ (recall that the measure of depositors is one).

Given the liquidity demand, type L banks face a liquidity problem. Each type L bank has to fully repay each depositor at date 1 . But the entrepreneurs to whom the L type bank made loans produce nothing at date 1 . Given that the portion of type L1 banks is $\alpha / 2$, total liquidity demand from type L1 banks in the morning of date $1(\mathrm{~s}=1)$ is $\alpha / 2$. Similarly, total liquidity demand from type L2 banks in the afternoon of date $1(\mathrm{~s}=2)$ is $\beta / 2$.

Each of type $\mathrm{H} 1$ and $\mathrm{H} 2$ bank receives $\gamma \mathrm{C}$ for a unit of deposit $(=1)$ from borrower firms in $\mathrm{s}=$ 1 or $\mathrm{s}=2$, unless depositors withdraw earlier than date 1 . For simplicity, assume that type $\mathrm{H} 1$ and $\mathrm{H} 2$ banks receive sufficient profit to fully pay deposit in the absence of bank runs. That is, $\gamma \mathrm{C}>1 .^{11}$ Thus type-H banks can have surplus amounting to $(\gamma \mathrm{C}-1)$ per deposit. Since bankers and entrepreneurs do not consume at date 1 , total liquidity surplus at date 1 is given by $(\mathrm{C}-1)$ per deposit, with type $\mathrm{H}$ banks providing $(\gamma \mathrm{C}-1)$ and entrepreneurs supplying $(1-\gamma) \mathrm{C}$. Given that the portion of type $\mathrm{H} 1$ banks is $(1-\alpha) / 2$, aggregate liquidity supply at $s=1$ is $(1-\alpha)(C-1) / 2$. Similarly, aggregate liquidity supply at $s=2$ could be $(1-\beta)(C-1) / 2$, unless depositors make early withdrawals. Then comparing liquidity demand from depositors and the supply by banks and entrepreneurs, there will be aggregate liquidity shortage in both $\mathrm{s}=1$ and $\mathrm{s}=2$ if $\alpha>(1-\alpha)(\mathrm{C}$ 1) and $\beta>(1-\beta)(C-1)$.

We assume that aggregate shock generates sequential liquidity shortages:

$$
\text { Assumption 1: } \alpha>(1-\alpha)(\mathrm{C}-1) \text { and } \beta>(1-\beta)(\mathrm{C}-1) \text {. }
$$

In particular, assume that total liquidity supply generated by H-type banks and their borrower firms in the morning and the afternoon of date $1(=(2-\alpha-\beta)(C-1) / 2)$ only meets liquidity demand from type $\mathrm{L} 2$ banks in the afternoon $(=\beta / 2)$. More specifically, assume

$$
\text { Assumption 1': }(2-\alpha-\beta)(\mathrm{C}-1) / 2=\beta / 2+\mathrm{e},
$$

where e is positive but infinitely small $\left(=0^{+}\right)$. This assumption simplifies the discussion below by making interest rates zero.

We also assume:

Assumption 2: $\alpha=\beta$.

which captures the fact that aggregate shocks persist within a stage of business cycles (date 1 here).

${ }^{11}$ While the assumption substantially simplifies the discussion, it is not critical to deriving the main results of the paper. When we also allow for the case where $\gamma \mathrm{C}<1$, the qualitative results of the paper do not alter. 


\section{Lender of Last Resort and Bailout}

The central authority's ability to bail out defaulted banks is constrained by its available resources. To make our point most starkly, we assume there exist no reserves for bailouts. Absent additional resources, full bailout is not feasible under Assumption 1'. Hence only a fraction of defaulted banks can be rescued. Let $\lambda$ denote the rate of bailout for date 1 (including both sub periods, $\mathrm{s}=1$ and $\mathrm{s}=2$ ), with $\lambda_{1}$ and $\lambda_{2}$ denoting the rates of bailout at $\mathrm{s}=1$ and $\mathrm{s}=2$, respectively.

Assume that the central authority chooses a partial bailout that satisfies the following feasibility condition:

$$
\lambda=\left(\lambda_{1}+\lambda_{2}\right) / 2 \leq \beta /(2 \alpha)
$$

It is evident that given Assumption 1' and 2, any bailout satisfying eq. (1) is feasible.

The central authority here brings no resources to the table at date 1 . So its role is principally a coordinating one to redistribute available liquidity in the system to allow continued operation of the largest fraction of the banking system. The central authority does it by guaranteeing the bank's repayment at date 2 (or by providing it a claim on date 2 goods), not by injecting liquidity at date $1 .^{12}$ Through its powers to redistribute liquidity, the central authority gives $\lambda_{1}$ fraction of the morning banks and $\lambda_{2}$ fraction of afternoon banks facing liquidity crises, claims on date 2 of the consumption good (or guarantees the banks' repayment at date 2).

To allow for the transfer of liquidity from the morning to the afternoon, we assume the existence of a financial market. The market opens twice at date 1: in the morning and the afternoon. An agent lends only to those banks whose repayment is guaranteed by the central authority at date 1 and, hence, only bailed-out banks can borrow money in the market.

For any level of bailout that satisfies eq. (1), there will be excess supply of liquidity in the market given Assumption 1'. Meanwhile, produced goods can be stored without depreciation between date 1 and date 2 . Then the interest rate between date 1 and date 2 will be determined to be zero $(\mathrm{r}=0)$. $^{13}$

${ }^{12}$ Diamond and Rajan (2003) distinguish between two types of bailouts: liquidity infusion and recapitalization. Liquidity infusion is to increase the effective supply of today' liquidity by taxing claimants on liquidity, while recapitalization is to provide a particular bank a claim on tomorrow's goods that would be supported by taxing tomorrow's wealth. In our benchmark model, we assume that the central authority does not have power and ability to raise taxes to bail out defaulted banks at date 1, while in Section 5 the assumption is relaxed.

${ }^{13}$ Suppose that $\mathrm{e}=0$ instead of $\mathrm{e}=0^{+}$as in Assumption 1'. Under the bailout rate $\lambda=\beta /(2 \alpha)$, total liquidity demand would then be equal to total liquidity supply at all levels of the interest rate, which makes the rate of interest rate indeterminate. 


\section{E. Confidence of Depositors}

We formulate confidence to be determined as an outcome of depositors' rational expectations based on limited information. Note that in the morning of date 1, the depositors in afternoonshock banks are not informed about the liquidity position of their banks. So the depositors' confidence does not depend on the health of the individual banks.

But the depositors with limited information form expectations regarding the chance of future bailouts, using information on the government's financial constraints and bailout policies. If they expect the chance of future bank bailouts to be less than one, they would not be certain of the safety of their deposits. So they may run even before they know the liquidity conditions of their banks. But if the chance of future bailouts is expected to be one, they would be certain that their deposits are fully protected regardless of whether their banks will turn out to be L type or $\mathrm{H}$ type. In this model, therefore, confidence is endogenously determined as a function of the bailout policy.

\section{F. Timing of Events}

At date 0 , depositors make deposits to banks. Then banks in turn lend all the deposits to entrepreneurs. There is no storage technology between date 0 and date 1 , which induces depositors to deposit all of their endowment at date 0 .

In the morning of date $1(\mathrm{~s}=1)$, a part of loan-side shocks occur. One half of banks (L1 and H1) receive a liquidity shock, and the other half (L2 and H2) do not yet receive a shock. Among the banks with morning shocks, $\alpha$ fraction turn out to be type L1 and the rest type H1 banks. Information on the shock arrives a little bit earlier than the shock itself. The information on the liquidity shock is revealed in the beginning of the morning of date 1 , but the shock itself occurs at the end of the morning.

The information on the type (and the resulting liquidity condition) of each morning-shock bank, together with aggregate shock ( $\alpha$ and $\beta$ ), is first revealed to the bank and the central authority. In response, the central authority announces its bailout policy on the morning-shock banks in potential liquidity crisis, together with the list of banks that will be bailed out. After the announcement of a bailout policy, depositors get the information on $\alpha, \beta$ and whether their banks belong to a morning-shock or afternoon shock bank. Depositors of morning-shock banks get to know also whether their bank is of H1 type or L1 type. Then depositors of morning-shock banks make their decision on deposit withdrawal, depending on the announced bailout policy. The depositors of afternoon-shock banks do not yet know their type at this time. But they form rational expectations on the liquidity condition in the afternoon of date 1 and decide on deposit withdrawal. As a result, there may occur runs on both morning-shock and afternoon-shock banks during the morning of date 1 .

At the end of the morning of date $1, \mathrm{H} 1$ banks receive $\gamma \mathrm{C}$ (per deposit) from their borrower firms and pay 1 to each depositor. Those L1 banks that are bailed out pay 1 to each depositor. Those that do not receive a bailout would be liquidated, and pay c to each depositor unless nobody has yet run for withdrawals. 
In the beginning of the afternoon of date $1(\mathrm{~s}=2)$, information on the liquidity shock for afternoon-shock banks that were not hit by bank runs during the morning $(s=1)$ is revealed to the central authority. Then it announces its bailout policy, together with the banks to be bailed out. As the information is revealed to depositors of afternoon-shock banks, they make decisions on deposit withdrawal. At the end of the afternoon, $\mathrm{H} 2$ banks receive $\gamma \mathrm{C}$ per deposit from borrower firms and pay 1 to each depositor. The L2 banks that are bailed out pay 1 to each depositor. But those that are not bailed out would pay c to each depositor after liquidation.

At the end of date 1, all the depositors consume what they get from banks. At date 2, borrower firms of type $\mathrm{L}$ banks that were bailed out during date 1 , produce $\mathrm{C}$ per deposit. They pay $\gamma \mathrm{C}$ per deposit to the banks, and keep the remainder, $(1-\gamma) \mathrm{C}$, for their own consumption. At the end of date 2 , entrepreneurs and bankers consume what they have earned so far.

\section{Simultaneous Versus Sequential Liquidity Shortages}

A distinguishing feature of our model is that liquidity shortages occur across banks sequentially, not simultaneously. This section shows how the introduction of dynamic liquidity shortages can drastically change the effect of bailout policy by comparing between the cases of one-period (static) and two-period (dynamic) liquidity shortages.

\section{A. Bailout Under Simultaneous Liquidity Shortages}

Unlike our model in the previous section, suppose that all the banks have loan-side shocks simultaneously in a point of time at date 1 . There is no distinction between type L1 and type L2 banks, nor between type $\mathrm{H} 1$ and type $\mathrm{H} 2$ banks. Then the chance of being a type $\mathrm{L}$ bank is $(\alpha+\beta) / 2$, while that of being a type $\mathrm{H}$ bank is $(2-\alpha-\beta) / 2$.

In this case, all the L type banks simultaneously face adverse loan-side shocks, which under Assumption 1' leads to an aggregate liquidity shortage without intervention. Since the bailout (i.e., recapitalization) can prevent a bank run without incurring any costs, it would be optimal for the central authority to bail out as many L type banks as possible within the feasibility condition (eq.(1)). ${ }^{14}$ Suppose that the central authority sets the bailout rate at

$$
\lambda^{*}=\lambda^{\max }
$$

where $\lambda^{\text {max }}$ is the maximum rate of bailout that satisfies eq. (1), that is, $\lambda^{\max }=\beta /(2 \alpha)$. Given Assumption 1' and the resulting excess supply of liquidity (that is, $\left.\left[(1-\alpha)(C-1) / \alpha-\lambda^{\max }\right]>0\right)$, the market interest rate between date 1 and date 2 is determined to be: $r=0$. So $\lambda^{\max }$ can be viewed as a maximum rate of feasible bailouts guaranteeing zero interest rates.

\footnotetext{
${ }^{14}$ Unless it satisfies the feasibility condition, there would be huge bank runs. See Section VI.A
} for the case of announcing the policy of infeasible bailouts. 
The central authority randomly chooses $\lambda^{\text {max }}$ portion of type L banks that will be bailed out, because type L banks are identical, and announces the list of the bailed-out banks. Meanwhile, no type $\mathrm{H}$ bank faces liquidity shortages given $\gamma \mathrm{C}>1$.

Under the bailout policy, those bailed-out L type banks will be able to borrow liquidity from $\mathrm{H}$ banks and their borrower firms in the market. Given zero interest rate, the value of the assets of the banks will then be: $\gamma \mathrm{C} /(1+\mathrm{r})=\gamma \mathrm{C}$, which is greater than the value of deposits $(=1)$. So depositors in those banks do not run for withdrawal.

But $\left(1-\lambda^{\max }\right)$ portion of type L banks that are not bailed out suffer bank runs. To repay their deposits, these banks will have to restructure their assets, the value (per deposit) of which will be: $c<1$. So the value of the assets of the banks is lower than the value of deposits. Therefore, the depositors run to withdraw deposits.

Taken together, runs occur only on L banks that are not bailed out. As a result, the portion of banks facing runs in the economy (denoted by $\mathrm{w}^{\mathrm{S}}$ ) is given by:

$$
\mathrm{w}^{\mathrm{S}}=\left(1-\lambda^{\max }\right)(\alpha+\beta) / 2 \text {. }
$$

Aggregate output (including output from early termination of project) of the economy at dates 1 and 2 are given by: $\mathrm{Y}_{\mathrm{t}=1}=\left[\left(1-\lambda^{\max }\right)(\alpha+\beta) / 2\right] \mathrm{c}+[(2-\alpha-\beta) / 2] \mathrm{C}$ and $\mathrm{Y}_{\mathrm{t}=2}=\left[\lambda^{\max }(\alpha+\beta) / 2\right] \mathrm{C}$, respectively. Then the sum of aggregate outputs for dates 1 and 2 in this case, denoted by $\mathrm{Y}^{\mathrm{S}}$, is

$$
\mathrm{Y}^{\mathrm{S}}=\left[\left(1-\lambda^{\max }\right)(\alpha+\beta) / 2\right] \mathrm{c}+\left[\lambda^{\max }(\alpha+\beta) / 2+(2-\alpha-\beta) / 2\right] \mathrm{C} \text {. }
$$

\section{B. Random Bailout under Sequential Liquidity Shortages}

Now returning to the model of sequential liquidity shortages in Section 2, we examine what would happen if the central authority announces a random bailout of $\lambda^{\max }$ fraction of defaulted banks (without consideration of timing) as in the simultaneous liquidity shortage case.

Given the assumption of a continuum of banks, a random bailout (independent of timing) is the same as an even bailouts (across morning and afternoon of date 1), under which $\lambda^{\text {max }}$ fraction of the banks defaulting in the morning and the same $\lambda^{\max }$ fraction of the banks defaulting in the afternoon are bailed out (recapitalized), that is,

$$
{ }_{1}=\lambda_{2}=\lambda^{\max } \text {. }
$$

With the government's commitment to bail out $\lambda^{\max }$ fraction of the L1 type banks, those designated for the bailout will be able to borrow money in the morning of date 1 . In the morning, liquidity supply is given by $(\mathrm{C}-1)(1-\alpha) / 2$ and liquidity demand is $\lambda^{\max } \alpha / 2$, which under Assumption 1', leads to zero interest rate $(r=0)$. It then follows that $\gamma \mathrm{C} /(1+\mathrm{r})=\gamma \mathrm{C}>1$, suggesting that the bailed-out L1 type banks will have more than enough to pay off all the deposits. Anticipating this, depositors in those banks do not have any incentive to run. 
It is also evident that those L1 type banks chosen not to be bailed out face bank runs. These banks will have to restructure their assets, which generates $c(<1)$ per deposit. Given the assumption that depositors not withdrawing until the end of date 1 get a pro rata share of the bank's remaining assets at the end of date 1 , the payoff of a depositor's waiting $\left(\mathrm{V}_{1}\right)$ is $\max [(\mathrm{c}-$ f)/(1-f), 0] where f represents the fraction of depositors who have already withdrawn. The payoff of a depositor's withdrawal during date $1\left(\mathrm{~V}_{2}\right)$ is 1 if less than $c$ fraction of the other depositors have withdrawn (that is, $\mathrm{f}<\mathrm{c}$ ), and 0 otherwise. It follows that for all $\mathrm{f} \in[0, \mathrm{c}$ ), we have $\mathrm{V}_{1}<\mathrm{V}_{2}$. Therefore, the depositors run to withdraw deposits.

Less evident, the crucial consequence of this policy is that runs occur on all the afternoon-shock banks in the morning of date 1, irrespective of whether they would eventually face an adverse loan-side shock or not. Given that liquidity surplus generated by H1 type banks and their borrower firms is fully used up, there would be a liquidity shortage in the afternoon of date 1 . In the morning, depositors of afternoon-shock banks do not yet know the type of their banks but expect liquidity shortage to occur in the afternoon. So they cannot be certain that they will receive the face value of deposits $(=1)$. With faltering confidence due to the expected liquidity shortage together with uncertainty on their types, they withdraw their deposits before the afternoon, leading to runs on all the afternoon-shock banks (see a more formal proof below). ${ }^{15}$

Proof. Consider an afternoon-shock depositor's decision on deposit withdrawal, depending on other depositors' actions. First, suppose that $0 \leq \mathrm{f}<\mathrm{f}^{\prime}$, where $\mathrm{f}^{\prime}$ denotes the fraction of withdrawn depositors that equalizes the value of the remaining assets of $\mathrm{H} 2$ banks to that of their remaining deposit liabilities (it can be easily shown that $f^{\prime}$ is less that $c$ ). This is the case where no or some other depositors have withdrawn deposits from afternoon-shock banks, but $\mathrm{H} 2$ banks will still be able to pay off all their deposits in their face vale $(=1)$. In this case, liquidity supply generated by $\mathrm{H} 2$ banks and their borrower firms in the afternoon would meet the afternoon liquidity demand by fraction $\lambda^{\max }(<1)$ of L2 banks at most. Given the bailout policy of $\lambda^{\max }$, the interest rate between the afternoon of date 1 and date 2 is zero. Then if the depositor waits until the end of date 1 , she would receive $\max [(\mathrm{c}-\mathrm{f}) /(1-f), 0]$ if the bank that she deposited turns out to be a L1 type bank that is not bailed out, and 1 otherwise. Therefore her expected payoff from waiting is given by: $V_{1}=\beta\left(1-\lambda^{\max }\right) \max [(c-f) /(1-f), 0]+\beta \lambda^{\max }+(1-\beta)<$ 1. Note that her payoff from early withdrawal $\left(\mathrm{V}_{2}\right)$ is 1 if less than $c$ fraction of the other depositors have withdrawn (that is, $\mathrm{f}<\mathrm{c}$ ), and 0 otherwise. Given $\mathrm{f}^{\prime}<\mathrm{c}$, therefore, we have $\mathrm{V}_{1}$ $<\mathrm{V}_{2}$ for $0 \leq \mathrm{f}<\mathrm{f}^{\prime}$.

Now suppose that $\mathrm{f}^{\prime} \leq \mathrm{f}<\mathrm{c}$, that is, many of other depositors have withdrawn so that even $\mathrm{H} 2$ banks will not be able to pay off all their deposits. In this case, her payoff from waiting would be given by $\max [(\mathrm{c}-\mathrm{f}) /(1-\mathrm{f}), 0]$ if it is a L1 type bank that is not bailed out, and $\max [\gamma \mathrm{C}(1-$ $\mathrm{f} / \mathrm{c}) /(1-\mathrm{f}), 0]$ otherwise. Therefore the expected payoff from waiting is given by: $V_{1}=\beta\left(1-\lambda^{\max }\right)$ $\max [(\mathrm{c}-\mathrm{f}) /(1-\mathrm{f}), 0]+\left(\beta \lambda^{\max }+(1-\beta)\right) \max [\gamma \mathrm{C}(1-\mathrm{f} / \mathrm{c}) /(1-\mathrm{f}), 0]<1$. Given that $\mathrm{V}_{2}$ is 1 for all $\mathrm{f}<\mathrm{c}$,

${ }^{15}$ The central authority cannot announce which among defaulted afternoon-shock banks will be bailed out during the morning of date 1 , because it does not yet have information on which afternoon-shock banks will be in default. 
and 0 otherwise, we have $V_{1}<V_{2}$ for $f^{\prime} \leq f<c$. In sum, it follows that for all $f \in[0, c), V_{1}<V_{2}$, that is, she will run for deposit withdrawal. $\|$

As a result, the portion of banks facing runs in the economy in this case (denoted by $w^{R}$ ) is given by:

$$
\mathrm{w}^{\mathrm{R}}=\left(1-\lambda^{\mathrm{max}}\right) \alpha / 2+\beta / 2+(1-\beta) / 2 .
$$

Aggregate output (including output from early termination) of the economy at dates 1 and 2 are given by: $\mathrm{Y}_{\mathrm{t}=1}=\left[\left(1-\lambda^{\max }\right) \alpha / 2+\beta / 2+(1-\beta) / 2\right] \mathrm{c}+[(1-\alpha) / 2] \mathrm{C}$, and $\mathrm{Y}_{\mathrm{t}=2}=$ $\left[\lambda^{\max } \alpha / 2\right] \mathrm{C}$. So the sum of aggregate output of dates 1 and 2 in this case, denoted by $\mathrm{Y}^{\mathrm{R}}$, is

$$
\mathrm{Y}^{\mathrm{R}}=\left[\left(1-\lambda^{\max }\right) \alpha / 2+\beta / 2+(1-\beta) / 2\right] \mathrm{c}+\left[\lambda^{\max } \alpha / 2+(1-\alpha) / 2\right] \mathrm{C} .
$$

From a comparison between eqs. (3),(4), (6) and (7), we can establish the following proposition.

\section{Proposition 1 Under Assumptions 1' and 2, we have

$$
w^{R}>w^{S} \text { and } Y^{R}<Y^{S} .
$$

Thus, a uniform bailout policy performs much worse under sequential rather than simultaneous liquidity shortages. When shortages occur sequentially, a commitment to uniform bailout leads to a dramatic loss of confidence, bank runs and output contraction relative to the situation when liquidity shortages are simultaneously revealed.

This suggests that a bailout policy taken without a due consideration on the dynamic nature of liquidity shortages may cause huge confidence losses and bank runs. In a static setting where all the banks receive loan-side shocks at the same time, bailouts could induce runs only on weak (illiquid) banks. But in a dynamic setting, the same bailout policy may generate runs also on strong banks as long as the banks' liquidity conditions are not yet known.

\section{EARly Versus Late Bailouts}

This section, therefore, explores whether differentiating the extent of bailout over time can help to more effectively manage confidence. First, consider the case where the authority announces bailing out all the morning-shock banks but not bailing out any afternoon-shock banks:

$$
\lambda_{1}=1 \text { and } \lambda_{2}=0
$$

After the information on the morning shock is revealed in the morning of date 1, the authority chooses and announces the banks to be bailed out (as in the case of random bailout in Section 3.2). Given Assumptions 1' and 2, the sum of the liquidity supply for the morning and the afternoon of date 1 is just large enough to meet the liquidity demand (by L1-type banks) in the morning. 
Under the early bailout policy, however, the central authority cannot fully bail out even the lateproject morning-shock (L1) banks. This is because there is no way of transferring resources from the future to the present here. Given Assumption 1', the authority can bail out only a half of L1 banks using the liquidity supply created by H1 banks and their borrower firms in the morning. As a result, runs occur on a half of L1 type banks that cannot be bailed out. Furthermore, early bailouts cannot ease liquidity shortages in the afternoon $(s=2)$. Therefore, depositors of afternoon shock banks lose confidence, which causes runs on all the afternoonshock banks.

As a result, the portion of banks facing runs under early bailouts, denoted by $\mathrm{w}^{\mathrm{E}}$, is

$$
w^{E}=\left(1-\lambda^{\max }\right) \alpha / 2+\beta / 2+(1-\beta) / 2,
$$

which is the same as $\mathrm{w}^{\mathrm{R}}$ in eq. (6).

The total output of dates 1 and 2 under early bailout policy, denoted by $\mathrm{Y}^{\mathrm{E}}$, is

$$
\mathrm{Y}^{\mathrm{E}}=\left[\left(1-\lambda^{\max }\right) \alpha / 2+\beta / 2+(1-\beta) / 2\right] \mathrm{c}+\left[\lambda^{\max } \alpha / 2+(1-\alpha) / 2\right] \mathrm{C},
$$

which is the same as $\mathrm{Y}^{\mathrm{R}}$ in eq. (7).

Now consider the case where the authority does not bail out any defaulted bank in the morning of date 1 but all the banks defaulted in the afternoon:

$$
\lambda_{1}=0 \text { and } \lambda_{2}=1
$$

Given the late bailout policy, there are runs on all the L1 type banks. Depositors know that any of type L1 banks will not be bailed out after they are hit by adverse loan-side shocks. So the banks will have to restructure their assets to pay off deposits. As a result, projects in the borrower firms of L1 banks will be prematurely terminated, and therefore the value of assets (per deposit) of any L1-type bank is $c$, which is less than what a depositor can have by withdrawing earlier than the other depositors $(=1)$. Anticipating this, depositors of any L1 type bank run to withdraw deposits.

Liquidation of all the L1 type banks generates a positive aggregate liquidity surplus in the morning of date 1 . The central authority will be able to use the aggregate liquidity surplus generated in the morning of date 1 (amounting to $[(1-\alpha) / 2](C-1)$ ), together with liquidity supplied by H2-type banks and their borrower firms in the afternoon of date 1 (amounting to $[(1-\beta) / 2](C-1)$, to bail out defaulted banks in the afternoon. The liquidity demand in the afternoon (from bailed-out L2 banks) will be $\beta / 2$ (given $\lambda_{2}=1$ ). Under Assumption 1', there will be no aggregate liquidity shortage in the afternoon of date 1, and hence all the defaulted L2 type banks will be bailed out in the afternoon. Afternoon-shock bank depositors do not yet know whether they are of type L2 or type H2. But they know that even when they turn out to be of L2 type, they will be certainly bailed out. With such boosted confidence, they do not withdraw deposits, and hence no runs occur on any of afternoon-shock banks (see a more formal proof below). 
Proof) In case of no deposit withdrawal by the other depositors ( $\mathrm{f}=0)$, a depositor's payoff from waiting would be given by $\min [1, \gamma \mathrm{C} /(1+\mathrm{r})]$ if she turns out to be of L2 type (which will be fully bailed out under $\lambda_{2}=1$ ), or 1 if she is of $\mathrm{H} 2$ type. Given Assumption 1', the interest rate is determined at $\mathrm{r}=0$, and $\min [1, \gamma \mathrm{C} /(1+\mathrm{r})]=\min [1, \gamma \mathrm{C}]=1$. So her expected payoff from waiting is given by: $\mathrm{V}_{1}=\beta \min [1, \gamma \mathrm{C} /(1+\mathrm{r})]+(1-\beta)=\beta+(1-\beta)=1$. Even if many other investors have withdrawn but the banks are still able to pay off the deposits $\left(\mathrm{f} \leq \mathrm{f}^{\prime}\right)$, the depositor's expected payoff from waiting is: $\mathrm{V}_{1}=\beta \min [1, \gamma \mathrm{C}(1-\mathrm{f} / \mathrm{c}) /(1-\mathrm{f})]+(1-\beta)=1$. Meanwhile, her payoff from early withdrawal $\left(\mathrm{V}_{2}\right)$ is 1 for $0 \leq \mathrm{f} \leq \mathrm{f}$. Therefore, given the assumption of lexicographic preference in Section 2.1, the depositor has no incentive to run unless a large portion (more specifically, more than f' fraction) of investors have already withdrawn. \|

So there are runs only on L1 type banks under the late bailout policy. As a result, the portion of banks facing runs in the economy in this case, denoted by $\mathrm{w}^{\mathrm{L}}$, is given by:

$$
\mathrm{w}^{\mathrm{L}}=\alpha / 2 \text {, }
$$

which is lower than $\mathrm{w}^{\mathrm{E}}$ in eq. (9).

Aggregate output (including output from premature termination) of the economy at each of dates 1 and 2 is given by: $\mathrm{Y}_{\mathrm{t}=1}=[\alpha / 2] \mathrm{c}+[(2-\alpha-\beta) / 2] \mathrm{C}$, and $\mathrm{Y}_{\mathrm{t}=2}=[\beta / 2] \mathrm{C}$. Then total output for dates 1 and 2 under late bailout policy, denoted by $\mathrm{Y}^{\mathrm{L}}$, is given by

$$
\mathrm{Y}^{\mathrm{L}}=[\alpha / 2] \mathrm{c}+[1-(\alpha / 2)] \mathrm{C} .
$$

which is greater than $\mathrm{Y}^{\mathrm{E}}$ in eq. (10).

Furthermore, if the central authority seeks to minimize banks runs (or maximize the value of aggregate output) for the two dates $(\mathrm{t}=1$ and 2$)$ under eq. (1), the optimal bailout policy is given by:

$$
\lambda_{1}^{*}=0 \text { and } \lambda_{2}^{*}=1
$$

We can thus establish the following proposition. 


\section{Proposition 2 Under Assumptions 1' and 2, we have}

$$
\begin{aligned}
& w^{E}\left(=w^{R}\right)>w^{L} \text { and } Y^{E}\left(=Y^{R}\right)<Y^{L}, \\
& \text { which leads to } \\
& \lambda_{1}{ }^{*}=0 \text { and } \lambda_{2}{ }^{*}=1 .
\end{aligned}
$$

The proposition suggests that late bailout policy reduces bank runs and generates higher aggregate output than early or random bailout policy. Under early or random bailouts, runs may occur on all the banks whose liquidity condition is not yet known (and which accounts for at least a half of the banking system) in exchange of rescuing a small number of banks which have already faced liquidity problems. Under late bailout, however, runs on those banks with late information revelation can be prevented. The superiority of late bailouts over early bailouts is ascribed partly to an asymmetry of inter-temporal resource transfer under aggregate credit constraint. Using storage technology, aggregate liquidity surplus generated now can be transferred to the future. Under aggregate liquidity shortage in the financial market itself, however, it is not possible to borrow from future through the financial market.

\section{Political Economy}

In the previous sections, we focused on the case where the central authority cannot raise taxes (for example, through inflation taxes) to bail out defaulting banks. This case possibly captures the fact that in emerging markets banks have a large portion of foreign-currency-denominated deposits or borrowings. Of course, the central authority of some countries may have taxing power strong enough to make full bailouts feasible. Even in such economies, however, late bailouts without taxation may receive more public support than full bailouts financed by taxation. We address this issue by analyzing a voting equilibrium in the basic model.

Recall that the population of depositors is far greater than that of bankers and entrepreneurs (Section 2.1). Therefore, political decision in our model is made primarily by depositors, whose measure is one. Depositors consists of four groups: depositors of late-project morning-shock (L1) banks, early-project morning-shock banks (H1), late-project afternoon-shock (L2) banks, and early-project afternoon-shock (H2) banks.

Consider, first, the case of full bailouts funded by taxation. Depositors in all banks receive the contracted value of deposit $(=1)$. Since depositors consume on date 1, they withdraw their claims on that date. So, in the morning of date $1(\mathrm{~s}=1)$, aggregate demand for liquidity (of depositors in morning-shock banks whose measure is $1 / 2$ ) is $1 / 2$. However, aggregate liquidity supply in $\mathrm{s}=1$ (generated by $\mathrm{H} 1$ banks and their borrower firms) is $(1-\alpha) \mathrm{C} / 2$. Therefore, aggregate liquidity shortage amounts to $[1-(1-\alpha) \mathrm{C}] / 2$ at that time.

Suppose that to finance the liquidity shortage, the central authority imposes taxes on deposit. So all the depositors of morning-shock banks (including depositors in the bailed-out) pay taxes in the morning of date 1 . As a result, depositors of morning-shock banks have the after-tax consumption $1-\tau^{*}$, while the tax rate $\left(\tau^{*}\right)$ is determined where total revenue raised from taxing 
all depositors of morning-shock banks equals net liquidity shortage: $\tau^{*}=1-(1-\alpha) \mathrm{C}<1$. Similarly, the depositors of afternoon-shock banks have the after-tax consumption $1-\tau^{*}$ where $\tau^{*}=1-(1-\beta) C<1$. So in this case, depositors in all of the four types of banks (L1, H1, L2 and $\mathrm{H} 2)$ will have after-tax consumption that is lower than the contracted value of deposit $(=1)$.

Next, consider the case of early bailouts without taxation. As shown earlier, the depositors of early-project morning-shock (H1) banks and fraction $\lambda^{\max }$ of late-project morning-shock (L1) banks receive the contracted value of deposit $(=1)$, which equals their net consumption given zero taxation. The depositors of fraction $\left(1-\lambda^{\max }\right)$ of late-project morning-shock (L1) are expected to have consumption goods of 1 with a chance of $c$ and 0 otherwise. Given the expectation of liquidity shortages in the afternoon of date 1, all the depositors of afternoonshock banks (L2 and H2) withdraw in the morning of date 1. They are expected to end up with having consumption goods of 1 with a chance of $c$ and 0 with a chance of (1-c).

Finally, consider the case of late bailouts without taxation. As shown before, the depositors of early-project morning-shock (H1) banks have the promised value of deposit (=1). All depositors of late-project morning-shock (L1) banks receive consumption goods of 1 with a chance of $\mathrm{c}$ and 0 with a chance of (1-c). Given no liquidity shortages in the afternoon of date 1 $(\mathrm{s}=2)$, the depositors of afternoon-shock ( $\mathrm{H} 2$ and $\mathrm{L} 2)$ banks receive the promised value of deposit (=1).

Given the distribution of net consumption (or utility) across four groups of depositors, we can predict the result of voting in various point of time. Here we first consider the voting that would occur in the morning of date $1(\mathrm{~s}=1)$, when depositors know whether they belong to L1, H1 or afternoon-shock banks (recall that they cannot know whether their banks belong to L2 or H2 type bank during the morning). Suppose for simplicity that nobody cannot withdraw before the voting. So at the time of voting, all the depositors of the defaulted banks that are not bailed out have the same expected consumption of $\mathrm{c}$. For simplicity, assume that $\alpha=\beta=1 / 2$, so that the measure of each type of banks is given the same as $1 / 4$.

To analyze a voting equilibrium in this case, first compare between full bailout and late bailout cases. As Table 2 indicates, depositors in H1, L2 and $\mathrm{H} 2$ banks will consume one unit of consumption good under late bailouts, but $\left(1-\tau^{*}\right)$ under full bailout funded by taxation. So they prefer late bailout to full bailout funded by taxation. Depositors in L1 banks will have expected consumption of $\mathrm{c}$ under late bailouts, but $\left(1-\tau^{*}\right)$ under full bailout funded by taxation. If we assume $\left(1-\tau^{*}\right)>\mathrm{c}$, depositors in L1 banks would prefer full bailout funded by taxation. ${ }^{16}$ As a result, 75 percent of depositors prefer late bailouts to full bailouts, and 25 percent prefer full bailouts to late bailouts. This suggests that even when taxation is a feasible option, full bailouts with taxes are not politically supported if late bailout policy is adopted.

\footnotetext{
${ }^{16}$ More specifically, if $(1-\alpha) \mathrm{C}>\mathrm{c}$, we have $\left(1-\tau^{*}\right)>\mathrm{c}$. If we instead assume that $(1-\alpha) \mathrm{C}<\mathrm{c}$, or $\left(1-\tau^{*}\right)<\mathrm{c}$, the policy of late bailout policy would receive 100 percent of votes in this case.
} 
Table 2. Voting Results

\begin{tabular}{||c|c|l|l|l||}
\hline & & FULL & EARLY \\
& BEASURE & $\begin{array}{l}\text { LATE } \\
\text { BAILOUT } \\
\text { WITH } \\
\text { TAXATION }\end{array}$ & $\begin{array}{l}\text { WITHOUT } \\
\text { TAXATION }\end{array}$ & $\begin{array}{l}\text { BAILOUT } \\
\text { WITHOUT } \\
\text { TAXATION }\end{array}$ \\
\hline L1 banks & $1 / 4$ & $1-\tau^{*}$ & $(1+\mathrm{c}) / 2$ & $\mathrm{C}$ \\
\hline H1 banks & $1 / 4$ & $1-\tau^{*}$ & 1 & 1 \\
\hline L2 banks & $1 / 4$ & $1-\tau^{*}$ & $\mathrm{c}$ & 1 \\
\hline H2 banks & $1 / 4$ & $1-\tau^{*}$ & $\mathrm{c}$ & 1 \\
\hline
\end{tabular}

Second, compare between late bailout and early bailout cases. In this case, depositors in L2 and $\mathrm{H} 2$ banks will consume one unit of consumption good under late bailouts, but have expected consumption of $\mathrm{c}$ under early bailouts. Therefore, they would prefer late bailouts to early bailouts. Depositors in L1 banks will have expected consumption of $\mathrm{c}$ under late bailouts, but $(1+c) / 2$ under early bailouts. So they would prefer early bailouts. Depositors in H1 banks are indifferent between the two bailout policy. Therefore, 50 percent of depositors prefer late bailouts to early bailouts, while 25 percent favors early bailouts to late bailouts. ${ }^{17}$

Now consider the voting for the three bailout options. Assume that if two options provide the same highest consumption for a group of depositors, the two options split equally the votes of the depositors. Then, the policy of full bailout with taxes would receive 25 percent of votes if $\left(1-\tau^{*}\right)>(1+\mathrm{c}) / 2$ or 0 percent of votes if $\left(1-\tau^{*}\right)<(1+\mathrm{c}) / 2$. The policy of early bailout would receive 12.5 percent of votes if $\left(1-\tau^{*}\right)>(1+\mathrm{c}) / 2$ or 37.5 percent of votes if $\left(1-\tau^{*}\right)<(1+\mathrm{c}) / 2$. Finally, the policy of late bailout would receive 67.5 percent of votes.

The above discussion leads to the following proposition.

Proposition 3 Under Assumption 1' and 2, the policy of late bailouts without taxation receives most public support.

The proposition suggests that even when the injection of liquidity financed by taxation is a feasible option, the full bailout with taxation is less favored than late bailouts without taxation. The intuition behind the result is straightforward. Under late bailouts, a majority of depositors would receive deposits $(=1)$ back without any loss. Under full bailout financed by taxation,

${ }^{17}$ If the voting is made only between full bailout and early bailout cases, more depositors may prefer full bailout with taxation. Under the assumption that $\left(1-\tau^{*}\right)>(1+\mathrm{c}) / 2$, depositors in L2 and $\mathrm{H} 2$ banks and a half of L1 banks would prefer full bailout funded by taxation to early bailout. As a result, the policy of full bailout with taxes receives 75 percent of votes, while the policy of early bailout without taxation receives 25 percent of votes. 
however, they would have to pay taxes, leading to a reduction in after-tax consumption. So they prefer late bailouts without taxes to full bailouts financed by taxation. ${ }^{18}$

Note that the timing of voting would not affect the proposition if it is expected that $\alpha$ and $\beta$ satisfy Assumption 1' and 2 at the time of voting. Suppose that information on $\alpha$ and $\beta$ are revealed to the depositors before date 1 (say, date 0.5 ) and voting is held at date 0.5 instead of the morning of date $1(\mathrm{~s}=1)$. At date 0.5 , depositors do not yet know the type of their banks. However, they expect their utility to be $\mathrm{u}^{\mathrm{L}}=(1 / 4) \mathrm{c}+(3 / 4)$ under late bailout and $\mathrm{u}^{\mathrm{F}}=1-\tau^{*}=$ $(1-\alpha) C$ under full bailout. Under $\alpha=\beta=1 / 2$ and Assumption 1 ', we have $u^{\mathrm{F}}=(1 / 2) \mathrm{C} \approx(3 / 4)<$ $(1 / 4) c+(3 / 4)=u^{L}$. Thus even before the morning of date 1 , depositors would favor the policy of late bailout without taxation rather than full bailouts funded by taxation. In this case, the policy of late bailout receives 100 percent public support.

\section{EXTENSIONS}

In this section, we extend our model to assess various practical strategies for bank bailouts. Not surprisingly, our model suggests caution against blanket guarantees and is more supportive of early (or even preemptive) closures. Some concerns with respect to early closures, however, may arise if knowing such a policy to be in effect, banks willfully hide information, or if early failures are the source of contagion. We now examine these issues.

\section{A. Blanket Guarantees and Preemptive Bank Closures}

In the previous sections, we assume that the central authority announces the policy of feasible bailouts, together with the banks to be bailed out. We now explore what would happen if the central authority announces a blanket guarantee that is not feasible. ${ }^{19}$ This analysis on blanket guarantees is important particularly because blanket guarantees, together with early bailouts, have been widely used to deal with likely systemic bank failures.

Consider the following sequence of events. At the beginning of the morning of date 1 , the central authority receives information on the aggregate shock ( $\alpha$ and $\beta$ ) and on the types of banks, while depositors do not. The authority announces blanket guarantees, which is not feasible. Depositors receive information on the aggregate shock but not on whether their banks are of L-type or H-type.

18 This political economy result may help to explain various restrictions imposed on the government's capabilities to bail out distressed banks in emerging markets, including liability dollarization (Rajan, 2004; Gulde and others; 2004).

${ }^{19}$ See Hoelscher and Quintyn (2003) for emergency liquidity support or blanket guarantees for that taken at the early stage of crisis by the governments of crisis countries such as Indonesia, Thailand, Mexico, and Turkey. 
Once the government announces a policy of blanket guarantees, it cannot selectively bail out, even though it knows the banks that are of $\mathrm{H}$ and L types. It is committed to bail out any type of banks if those banks experience a liquidity problem. But depositors know that the government's blanket guarantee policy is not credible. Depositors face uncertainty with respect to who will be bailed out, because they cannot make a distinction between bank types.

Hence, under blanket guarantees, the depositors in type L1 and even type H1 banks withdraw on the morning of date 1 . They know that given information on $\alpha$ and $\beta$, at most fraction $\lambda^{\text {max }}$ of the banks can be bailed out, and so their expected payoff from waiting is lower than that from early withdrawal $(=1)$. As both L1 type and $\mathrm{H} 1$ type banks have runs, there will be liquidity shortage in the afternoon of date $1(\mathrm{~s}=2)$. The afternoon-shock bank depositors, who do not yet know the type of their banks, will also withdraw given the expectation of liquidity shortage in the afternoon of date 1 .

The above discussions suggest that runs occur on all the banks in the morning of date 1 . As a result, the portion of banks facing runs in the economy in this case, denoted by $\mathrm{w}^{\mathrm{F}}$, is given by $\mathrm{w}^{\mathrm{F}}=1$. Total output for dates 1 and 2 is: $\mathrm{Y}^{\mathrm{F}}=[(\alpha / 2)+(1-\alpha) / 2] \mathrm{c}+[(\beta / 2)+(1-\beta) / 2] \mathrm{c}=\mathrm{c}$. It then follows that

$$
\mathrm{Y}^{\mathrm{F}}<\mathrm{Y}^{\mathrm{R}}=\mathrm{Y}^{\mathrm{E}}<\mathrm{Y}^{\mathrm{L}}
$$

Thus, an infeasible policy of full bailouts could bring about the worst outcome. Total output under blanket guarantees would be even lower than under early bailouts. ${ }^{20}$ The intuition behind the result is straightforward. Under the policy of early bailouts, the central authority announces the banks to be bailed out. As a result, runs occur only on the banks that are not bailed out, not on the banks that are bailed out. Under infeasible blanket guarantees, the authority cannot differentiate between banks to be bailed out and those to be liquidated, and the announcement of full bailouts is not credible. So the policy of blanket guarantees raises uncertainty, leading to faltering confidence of depositors in all the banks, and runs can occur on both type $\mathrm{L}$ and type $\mathrm{H}$ banks.

So, not surprisingly, our model suggests caution against blanket guarantees and is more supportive of early closures by liquidity-constrained governments. Our model further suggests that even when aggregate liquidity shortage does not occur today, closures of some weak banks in advance could be desirable as long as liquidity shortage is expected to take place tomorrow.

To discuss preemptive bank closures, suppose that the central authority has reserves for bailout (accumulated in the past) just large enough to meet aggregate shortage in the morning of date 1. So if the reserve is used in the morning, there will be no aggregate liquidity shortage in the morning, nor runs on morning-shock banks. However, there will be liquidity shortages in the afternoon of date 1 given Assumption 1'. As a result, all the depositors of afternoon-shock

${ }^{20}$ If feasible, blanket guarantees or full bailout could be optimal. So it would be important to check the feasibility before announcing such a policy. 
banks, who do not yet know their type, will run to withdraw deposits in the morning. Thus, in this economy, welfare is improved when the central authority adopts a policy of preemptive bank closures in the morning of date 1. Using the resources saved from the policy of preemptive closures of L1 type banks in the morning, the authority can bail out all the L 2 type banks in the afternoon. So no depositor of afternoon-shock banks withdraws deposits, and no run occurs on any afternoon-shock bank. Consequently, the preemptive bank closures reduce the portion of banks facing bank runs.

\section{B. Potential Crisis Delays Through Information Hiding}

Does the policy of late bailouts create an incentive for banks to hide their type so that the ones who suffer the morning shock and know, therefore, that they will not be bailed out have an incentive to hide their type to be bailed out along with those that suffer the afternoon shock? Would such an incentive weaken the relevance of the late bail out policy?

Suppose that all the banks can delay the revelation of their true type for the same length of time. A morning-shock bank can hide the information until the beginning of the afternoon, i.e., when the afternoon-shocks are revealed. The morning-shock bank can thereby plan to join the afternoon-shock banks in the bailout. However, an afternoon-shock bank can also hide its type for an equal length of time, until the beginning of the evening. Assume, moreover, that a bank's hiding its type incurs a positive cost to the banker.

Thus, if L1-type banks delay the revelation of their type, L2-type banks would do the same, delaying the revelation of their type to the evening. Therefore, in equilibrium, the relative timing order of information revelation between L1-type and L2-type banks would not change. Furthermore, given the positive cost of hiding, even L1-type banks would not try to delay the revelation of their type. So the problems and solutions in this variant of the model are reduced to those of the basic model. This suggests that even under potential hiding of liquidity conditions by banks, the main results of our paper would not alter.

The above discussion could be extended to the case where the equality of delay technology is true in a stochastic sense. Suppose that the chance of delay possible by morning and afternoon banks is the same at $\chi(<1)$, so that $\chi$ fraction of morning banks may reveal their type at the same time with $(1-\chi)$ fraction of afternoon banks. Also suppose that aggregate liquidity is just enough to bail out all the afternoon-shock banks with adverse loan-side shocks and $\chi$ fraction of morning shock banks with adverse shocks, and that the government takes the policy of closing the banks whose liquidity problems are revealed in the morning, but bailing out the banks whose types are revealed in the afternoon or evening. In this case, as long as the cost of hiding exceeds a certain threshold level, L1-type banks would not have incentives to delay the revelation of their type though they know that there is a positive chance of a successful delay.

Even in the case where the cost of hiding is lower than the threshold level, the late bailout policy remains valid. In this case, the strategy of hiding may privately beneficial and therefore L1-type banks would try to delay the revelation of their type given the above bailout policy. The response to this, however, should not be to abandon but to strengthen a late bailout policy. If the government takes a stronger late bailout policy--bailing out only the banks whose shocks are 
revealed in the evening (so not bailing out those with shocks reveled in the afternoon)--, L1banks would not have incentive to delay the revelation of their type. Furthermore, if the hiding is related to regulatory deficiencies, then the right policy strategy would be to continue to adopt a late bailout policy but complement that with auditing and regulatory reform to prevent the hiding of information. By imposing severe penalties on hiding, such reforms would raise the cost of hiding and therefore discourage banks from hiding information. ${ }^{21}$

\section{Contagion Through Interbank Loans}

In the previous sections, we have excluded the potential of contagion in discussing the strategy of bank bailouts. Financial contagion may occur, for example, through interbank loans, as in Allen and Gale (2000). In the presence of contagion, the failure to bail out those experiencing early distress may magnify the problems of the banking system, creating a presumption of tilting policy back to early bailouts. However, even in the presence of interbank loans, the policy of late bailouts is optimal as long as there remain aggregate liquidity shortages.

To introduce interbank loans, suppose that some afternoon-shock banks are net lenders to morning-shock banks. When a morning-shock bank that has borrowed from an afternoon-shock bank faces a liquidity shock, it would not be able to repay its obligations in the afternoon and, as a result, the adverse shock could be transmitted to the afternoon-shock bank. Thus, bailout of illiquid morning-shock banks, by allowing them to make repayments, could limit the effect of contagion on afternoon-shock banks.

More specifically, the chance of an afternoon-shock bank's having an adverse loan-side shock $(\beta)$ depends on an aggregate liquidity shock, the contagion through interbank loans, and the bailout ratio of illiquid morning-shock banks as:

$$
\beta=\beta^{\prime}+q\left(1-\lambda_{1}\right), \quad 0<\beta^{\prime}, q<1
$$

Here $\beta$ ' represents the portion of $\beta$ that is affected by an aggregate loan-side shock. In recessions, $\beta$ ' becomes larger as does $\alpha$. In addition, q captures net lending by afternoon-shock banks to morning-shock banks. If $q$ is zero, there are no interbank loans and we are back to our basic model without contagion through interbank loans. The ratio of the first period bailout, $\lambda_{1}$, ranges between 0 and $\lambda^{\max }$ where $\lambda^{\max }=\beta /(2 \alpha)$, as in the basic model.

Suppose that there is aggregate liquidity shortage, generated by an adverse aggregate shock. For simplicity, assume that an adverse aggregate shock raises both $\alpha$ and $\beta$ ', and generates dynamic liquidity shortages large enough to meet: $\left(2-\alpha-\beta^{\prime}-\mathrm{q}\right)(\mathrm{C}-1)=\beta^{\prime}+\mathrm{q}$.

${ }^{21}$ Banks' hiding of their problems is often thought to have contributed to the protracted problems of the banking system and, by dosing so, have raised social costs in some countries. So it warrants some preventive polices including penalties on the hiding of information. 
So when $\lambda_{1}$ is at its minimum $(=0)$, total liquidity supply generated by H-type banks and their borrowers in the morning and the afternoon of date 1 can satisfy only liquidity demand from L2-type banks in the afternoon.

Consider, first, the case where the adverse aggregate shock is large compared to contagion effect through interbank loans, more specifically $\alpha / q>C$. In this case, the liquidity available in the afternoon (after bailing out fraction $\lambda_{1}$ of morning-shock banks) is given by (2- $\alpha-\beta$ ' $-\mathrm{q}(1-$ $\left.\left.\lambda_{1}\right)\right)(\mathrm{C}-1) / 2-(\alpha / 2) \lambda_{1}$. Meanwhile, the liquidity demand in the afternoon is given by $\left(\beta^{\prime}+\mathrm{q}(1-\right.$ $\left.\left.\lambda_{1}\right)\right) / 2$. Then the liquidity shortage in the afternoon $(S)$ is: $S=[\alpha-q C] \lambda_{1} / 2$. Given $\alpha / q>C$, we have $S>0$ (that is, there will be liquidity shortages in the afternoon) for all positive values of $\lambda_{1}$. This suggests that any policy involving early bailouts $\left(\lambda_{1}>0\right)$ will cause liquidity shortage in the afternoon, which will cause runs on all the afternoon-shock banks. However, under the policy of late bailouts with full early closures $\left(\lambda_{2}=1\right.$ and $\left.\lambda_{1}=0\right)$, there will be no liquidity shortage in the afternoon. So bank runs can be minimized.

Now consider the case of a less severe liquidity crisis, where $\alpha / q<C$. In this case, with any positive values of $\lambda_{1}$, there will be liquidity surplus in the afternoon (that is, $S<0$ ). So there is large enough liquidity to ensure the bailout of all the illiquid banks in the afternoon $\left(\lambda_{2}=1\right)$ and a certain portion, say $\lambda_{1}{ }^{\prime}(<1)$ of illiquid banks in the morning. Even in this case, however, an early bailout policy of $\lambda_{1}>\lambda_{1}{ }^{\prime}$ and $\lambda_{2}<1$ would creates runs on all afternoon-shock banks. Therefore, even in a less severe liquidity crisis that allows a positive early bailout, full late bailouts $\left(\lambda_{2}=1\right)$ need to be assured.

The above discussions suggest that even in the presence of contagion through interbank loans, a late bailout policy (combined with at least some early closures) could most effectively prevent bank runs as long as there are aggregate liquidity shortages. The policy of early bailouts is suboptimal unless it can prevent aggregate liquidity shortages. Therefore, the main result of our basic model continues to hold.

In addition, an early bailout could be dangerous unless it can ensure that there will be no liquidity shortage in the future (and so that there will be full late bailouts). In the presence of contagion through interbank loans, some early bailouts provide a benefit of reducing the size of loan-side shocks in the future. That may explain why many governments have tried hard to bail out banks in trouble at the early stage of banking crisis. But our model suggests that there could be a pecking order of bailouts: any bailout of banks with early distress should be done only after bailouts of all the late distress banks are ensured. Otherwise, early bailouts could prompt large bank runs. $^{22}$

\footnotetext{
${ }^{22}$ We may also examine the situation where the banks that get into trouble earlier may have more illiquid loans, by assuming that the chance of illiquidity in morning shock banks is higher than that of afternoon shock banks: $\alpha>\beta$. We can show that the optimal pecking order of bailouts also applies to this case. In addition, the smaller the chance of illiquidity in afternoon banks $(\beta)$ is compared to that of morning shock banks $(\alpha)$, the less resource is required for late bailouts. Furthermore, if moral hazard is introduced into the model, the closures (i.e.,
} 
Furthermore, even under uncertainty with respect to the seriousness of an unfolding crisis (in terms of liquidity shortages), the optimal policy could require late bailouts rather than early bailouts. Suppose that the chance that an early bailout will generate liquidity shortages is a half, the same as the chance that it will not. In this case, maximizing expected aggregate output would continue to require late bailout. This is because the early bailout policy generates much greater output loss in the event of liquidity shortages (with a chance of a half) than the output gain (due to containing contagion through interbank loans) in the event of no liquidity shortages.

\section{Conclusions}

In this paper, we have examined the emerging market government's strategy for bailing out banks when liquidity shocks hit banks over time, rather than at the same instant, and the government cannot credibly commit to bail out all banks on account of its own financial limitations. In this situation, we suggest that at the start of a crisis, the government refrain from bailing out banks facing early shocks and focus its entire effort on ensuring the survival of those that are exposed to late shocks. This result arises from the consideration that if the resources to bail out banks subject to late shocks are not available, then all such banks, whether each of them will actually face distress later or not, will suffer a loss of confidence and runs by depositors. Thus, the effort to save a small number of select banks that are already known to have experienced distress raises the probability of runs on a majority of banks on whom information is to become available only later.

We found that such a strategy of retaining the ability to bail out banks that face late distress is not only optimal when the government's fiscal resources are limited but would receive political support from constituents who would face higher taxes if the government were to extend a commitment to a complete bailout of all potentially distressed banks.

We also used the insights of the model to examine several practical policy strategies. We concluded against providing blanket guarantees and in favor of arranging early closures. Early bailouts including blanket guarantees taken by liquidity-constrained governments have often failed at managing investor confidence or exacerbated the banking crisis. A contribution of this paper is to provide an explanation for such frequently observed failures of early bailout policies. We also found that the late-bailout strategy remains advisable when the incentives for those banks in early distress to hide information are taken into consideration. The policy can be complemented by regulatory tightening which raises the cost of hiding information. Finally, even in the presence of contagion, the optimal policy could require late bailouts rather than early bailouts as long as there is an aggregate liquidity shortage.

punishment) of the bank in early trouble (whose chance of being of bad type is higher) would help mitigate the moral hazard problem as well. 


\section{References}

Allen, Franklin, and Douglas Gale, 2000, "Financial Contagion," Journal of Political Economy, Vol. 108, pp. 1-33.

Blanchard, Olivier, and Michael Kremer, 1997, "Disorganization," Quarterly Journal of Economics, Vol. 112(4), pp. 1091-1126.

Burnside, Craig, Martin Eichenbaum, and Sergio Rebelo, 2001, "Prospective Deficits and the Asian Currency Crisis," Journal of Political Economy, Vol. 109, pp. 1155-97.

Chopra, Ajai, Kenneth Kang, Meral Karasulu, Hong Liang, Henry Ma, and Anthony Richards, 2002, "From Crisis to Recovery in Korea: Strategy, Achievements, and Lessons," in Korean Crisis and Recovery, ed by David T. Coe and Se-Jik Kim, pp. 13-104 (Washington and Seoul: International Monetary Fund, and Korean Institute for International Economic Policy).

Cordella, Tito, and Eduardo Levy Yeyati, 2003, "Bank Bailouts: Moral Hazard vs. Value Effect," Journal of Financial Intermediation, Vol. 12, pp. 300-30.

Diamond, Douglas, 2004, "Presidential Address, Committing to Commit: Short-term Debt When Enforcement Is Costly," Journal of Finance, Vol. 59, pp. 1447-79.

—_, and Phillip Dybvig, 1983, "Bank Runs, Deposit Insurance, and Liquidity," Journal of Political Economy, Vol. 91, pp. 401-19.

Diamond, Douglas, Raghuram Rajan, 2001, "Liquidity Risk, Liquidity Creation and Financial Fragility: A Theory of Banking," Journal of Political Economy, Vol. 109, pp. 87-327.

— , 2002, "Bank Bailouts and Aggregate Liquidity," American Economic Review, Papers and Proceedings, Vol. 92 (2), pp. 38-41.

__ 2003, "Liquidity Shortages and Banking Crises,” NBER Working Paper No. 10071 (Cambridge, Massachusetts: National Bureau of Economic Research).

Goodhart, Charles, and Haizhou Huang, 2000, “A Simple Model of an International Lender of Last Resort,” IMF Working Paper No. 00/75 (Washington: International Monetary Fund).

Gulde, Anne-Marie, David Hoelscher, Alain Ize, David Marston, and Gianni De Nicolo, 2003, Financial Stability in Dollarized Economies, IMF Occasional Paper No. 230 (Washington: International Monetary Fund).

Hoelscher, David, and Marc Quintyn, 2003, Managing Systemic Banking Crises, IMF Occasional Paper No. 224 (Washington: International Monetary Fund). 
Jeanne, Olivier, and Charles Wyplosz, 2001, "The International Lender of Last Resort: How Large Is Large Enough?” NBER Working Paper No. 8381 (Cambridge, Massachusetts: National Bureau of Economic Research).

Johnson, Simon, and Todd Mitton, 2003, "Cronyism and Capital Controls: Evidence from Malaysia," Journal of Financial Economics, Vol. 67, pp. 351-82.

Kim, Se-Jik, 2004, “Timing of International Bailouts,” IMF Working Paper 04/9 (Washington: International Monetary Fund).

Krugman, Paul, 1998, “The Confidence Game: How Washington Worsened Asia’s Crash,” http://www.pkarchive.org/crises/krugman1.html.

Lerrick, Adam, and Allan Meltzer, 2003, "Blueprint for an International Lender of Last Resort,” Journal of Monetary Economics, Vol. 50, pp. 289-303.

Mody, Ashoka, 2004, "What Is an Emerging Market?," IMF Working Paper 04/177 (Washington: International Monetary Fund).

Rajan, Raghuram, 2004, "Dollar Shortages and Crises," (Unpublished; Washington: International Monetary Fund). 